\title{
From Canon to Context
}

\author{
Reading Paul in a time of cultural complexity
}

\author{
Halvor Moxnes
}

The article traces the development of my own scholarly work on Paul from the individualism of «justification by faith» as the theological canon during my student period, to studies of Paul within his historical context and his efforts to unite Jews and non-Jews. The changes in my own studies took place within the larger shifts in New Testament studies from a German, Protestant hegemony to an American, non-confessional scene. The historical-critical method was supplemented with other methods, illustrated here by studies of honour and shame societies. In conclusion, I outline how these changes have influenced my own teaching of Paul, as a contextual theologian.

Keywords: canon, context, honour and shame, reception history

\section{Introduction}

What role does the Lutheran heritage play in my scholarly work? The invitation from the editors of Studia Theologia to reflect on this question presents an opportunity of taking stock of Nordic New Testament scholarship. The letter of invitation says: "Biblical scholarship is both theologically and historically closely connected to the reformation and for that reason still has a central position and function in the theological programs offered at the Nordic theological faculties." However, this argument is weakened by the changes that have taken place both within theological studies at large and within New Testament studies in particular in recent decades. Several of the former theological faculties have lost their independent position and have become integrated into larger units of humanities and religious studies. Those who have retained their independent position have established programs of religious or interreligious studies in addition to theological programmes. This development has altered the context of theological studies.

Nordic New Testament studies have also expanded over a couple of generations from belonging to a German, mainly Lutheran sphere to a much more international and nonconfessional context, dominated by the American scene. In a Nordic context Heikki 
Räisänen in Helsinki was the main proponent of this change, both in exegetical studies but especially in moving New Testament studies from a confessional, theological interest to a history of religion approach. ${ }^{1}$ As a result, New Testament studies now take place in a religious and social context that is no longer uniform and dominated primarily by the Lutheran tradition; it can be better described as a situation of cultural complexity.

Since I have experienced these changes within my own academic career I shall try to trace this development within my work in Pauline studies. I think that by and large my journey as a New Testament scholar is fairly typical of the changes in the field, but in my case I was exposed to the changes earlier than other European colleagues. In the early 1970s I was fortunate to come to Yale University which at that time was a centre for new approaches in New Testament studies, ${ }^{2}$ both related to classical literature and epistolography and to sociology and social anthropology.

I shall start by outlining the situation I experienced as a student of theology in the 1960s and 70s. My own research started with a dissertation on Paul's understanding of God in Romans; I continued with the influence from social anthropology, reading Paul's letters within their cultural context of Mediterranean society in the $1^{\text {st }}$ century, and ended up placing my own readings within the context of the history of reception. On this basis my own teaching of Paul for recent student groups has developed a different profile from that of my youth.

\section{Paul as Canon: learning Theology with Paul}

When I choose to focus on teaching and studies of Paul's letters it is of course because Paul was so central for Reformation theology, and that he has continued to be important through the history of Biblical studies ever since. In the 1960s and 70s there was a special focus on the importance of Paul's theology as part of the discussion of the New Testament as canon. ${ }^{3}$ Ernst Käsemann dedicated his edited volume Des Neue Testament als Kanon to the Faculty of Theology in Oslo. In his summary to the volume Käsemann provides his answer to the importance of canon. ${ }^{4}$ He finds it in the combination of Christology and the message of justification by faith in Paul, so that Christ embodies the justification of the ungodly. 
At the Faculty of Theology in Oslo at this period especially Inge Lønning and Jacob Jervell were influenced by Käsemann. His views were expanded by Inge Lønning in his Kanon im Kanon. Zum dogmatischen Grundlagenproblem des neutestamentlichen Kanons. As a systematic theologian Lønning was very much an interpreter of texts, and Paul's letters were among the texts that were most important to him. The canon that Lønning found in Paul's theology was identical with ,the Gospel“ in Gal 6:16. Since Paul was the carrier of this gospel he shared in its authority. ${ }^{5}$

The New Testament exegete Jacob Jervell did not enter into theoretical discussions of the importance of canon, but he was concerned about the theological relevance of the historical-critical exegesis of Paul's letters. That becomes visible in his commentary to Paul's letter to the Romans, Gud og hans fiender. In the preface, Jervell emphasizes his goal for the students with the book: "to learn as much as possible about the letter to the Romans has been less important for me than to learn theology with Romans." ${ }^{6}$ In Jervell's lectures, Paul's theology became a normative theology, valid for today. Therefore, Jervell could easily go from a historical observation to an existential interpretation, for instance when he made the transition from an historical statement about God's salvation of Jews and Greeks in Romans 3 to the salvation of the modern individual, whose only possibility is to submit to God and believe in Him. ${ }^{7}$ However, in Jervell's interpretation this existentialism did not remain merely individualism. Like Käsemann, Jervell developed Bultmann's teaching of God's justification by faith to imply God's power over the world as part of his covenant. ${ }^{8}$ The result was a teaching on Paul and justification by faith combined with a creation theology with a strong aspect of social responsibility, and that made it attractive to students in this period of political activity.

\section{From Justification by Faith to "for Jews and Greeks"}

Theological studies in Oslo in the 1960s and 70s were heavily influenced by German Protestant theology. As it turned out, times were changing; there was less teaching of German in Norwegian schools and therefore fewer students could read German. In the curriculum for theological studies there was a transition to literature in English with less focus on the confessional background of the authors. I found myself in the forefront of this trend with studies for my doctoral thesis in the USA, at first at Yale with the Norwegian professor Nils A. Dahl. ${ }^{9}$ My studies resulted in Theology in Conflict. Studies in Paul's Understanding of God in 
Romans. Its focus was on God-language in Paul's re-telling of the Abraham story in Romans 4. Read as Paul's support for his theological statement in 3:21-31, chapter 4 is at the very centre of expositions of Paul's teaching of righteousness through faith. However, my perspective was different. I was primarily interested in exploring the function of Paul's Godlanguage within the context of the various groups that Paul addresses in that chapter. Critical of the existentialism of Bultmann's thesis that each statement about God is at the same time a statement about man, I wanted to explore the historical context of Paul's statements about God and their collective perspective. ${ }^{10}$ My main thesis was that for Paul, speaking of God meant to speak of "Jews and Greeks" to overcome the conflicts between them and to create unity between these groups. ${ }^{11}$

In my conclusion I pointed out that Paul's theology arises from conflict situations, and I argued that to create unity between conflicting groups ought to be the "place" for doing theology to-day as well. ${ }^{12}$ Thus, I saw the parallel situations between "then" and "now" in collective relations between groups, not so much in individualism. ${ }^{13}$ In hindsight it is easy to recognize that the social context of my reading of Paul was the Vietnam War (very present in the American mind in this period), protests against colonialism and oppression of the indigenous Indian population.

\section{"Not Ashamed of the Gospel": The Cultural Context of Paul.}

The last part of the $20^{\text {th }}$ century saw a development of new methods in New Testament studies, some within the area of literary studies, some inspired by sociology and social anthropology. Other developments were results of new approaches, for instance reading texts from a feminist or gender standpoint. ${ }^{14}$ The result was that traditional historical-critical methods lost their hegemony. In Pauline studies the hegemony of an interpretation focused on individual belief and justification by faith was challenged. New scholarly trends are often the result of changes in cultural paradigms. The growth of social sciences in both research and teaching was part of a shift of focus in the general social and political context from the individual to social groups and group relations, which also influenced New Testament studies. $^{15}$ 
However, there are often individual stories behind such changes, and in my case coming to the USA was an encounter with cultural complexity. Norway in the early 1970s was still a homogenous white monoculture, while the USA gave the impression of being a society with many cultures. I realized that there were similarities between trying to understand a contemporary foreign culture and interpreting New Testament texts in their foreignness: what were the main values and the main issues in people's lives; what were they most concerned about? Social anthropologists with their long experience in encountering foreign cultures and in reflecting on the cultural differences provided a help to study the New Testament as a foreign world. In the USA, I encountered colleagues who had established a collaboration named the Cultural Context Group, ${ }^{16}$ interpreting the New Testament by help of models from social anthropology. Moreover, upon returning to Oslo I have been greatly helped by friends and colleagues among Norwegian social anthropologists. ${ }^{17}$ Members of the Context Group have been criticized for using generalized anthropology, for instance about Jews and Arabs, which may contribute to preserving stereotypes. ${ }^{18}$ Nevertheless, I think that social anthropology and other social sciences have showed their usefulness by providing new perspectives for reading New Testament texts.

I shall give one example from my first attempts to use social anthropology in the study of a text from Paul. ${ }^{19}$ The passage in Rom 1:16-17 is central to discussions of righteousness by faith in Paul:

For I am not ashamed of the gospel; it is the power of God for salvation to everyone who has faith, to the Jew first and also to the Greek. ${ }^{17}$ For in it the righteousness of God is revealed through faith for faith; as it is written, The one who is righteous will live by faith.

Instead of going directly to the central theological concepts in this text, I started with the apparently insignificant phrase: "For I am not ashamed of the gospel," and I asked what it could tell us about the cultural context of Paul. This small phrase opened up for a study of honour and shame as central values in Paul's world, the Mediterranean in the first century. I was inspired to this study by an article that compared Latin American and Norwegian societies. ${ }^{20}$ The main point of the article was that Norwegian society was characterized by guilt feeling, expressed primarily in the private sector of life. Latin Americans, on the other hand, lived their lives more on a public arena. Consequently they were more exposed to evaluations from others, be it positive (honour) or negative (shame). This comparison opened 
up for me an awareness that in reading Paul I had taken Norwegian mentalities for granted, and therefore I had read Paul within the same paradigm.

As a result I started to explore terms for honour and shame in Paul's letter to the Romans. To my surprise I found that they were spread throughout the letter, and that they were used to express different social relations. A study of Paul's vocabulary shows that honour and shame play an important part in Romans, with words for honor, to honour, to claim honour (boast), and words for shame, to put to shame, etc. ${ }^{21}$ These terms are found in all sections of the letter and they are more evenly distributed than terms for justification and righteousness. This terminology points to social structures and their mental underpinnings, the commonly accepted way in which people see themselves and their relations to others. Therefore, this strong presence of honour and shame language is important to understand the context of Paul's argumentation.

Robert Jewett, author of influential commentaries on Paul's Letter to the Romans, found that the prevalence of honour and shame categories must overrule individual categories in the interpretation of the letter:

\footnotetext{
The most troubling of these challenges was the slowly emerging awareness that the dominant paradigm for interpreting justification by faith as individual forgiveness of sins was not supported by the actual wording of Romans. Although every commentary on my shelf followed the Augustinian scheme of justification as individual forgiveness, Halvor Moxnes broke this tradition by showing that the word fields of "honor, dishonor, shameless, be ashamed, put to shame, glory, glorify, praise, boast and boasting" were actually more central in Romans. This focus on honor and shame related to the central purpose of the letter as Moxnes understood it, "to bring together believing Jews and non-Jews in one community." This meant that Paul was seeking to overcome shameful exclusion, which could not be accomplished by forgiveness, which was in any event a secondary issue. ${ }^{22}$
}

\section{The communal Focus of Justification by Faith in an Honour and Shame Society}

Re-reading Robert Jewett's comments now, I realize that what I did in Theology in Conflict in 1980 and in essays on honour and shame in Romans a few years later, ${ }^{23}$ actually contributed to the shift towards "the New Paul" approach in Pauline studies, breaking with justification by faith as the dominant paradigm. However, I was not aware of this connection at the time. ${ }^{24}$ In these studies I had only one reference to Krister Stendahl's signal essay with his protest against the individualism of psychological readings of Paul. ${ }^{25}$ Moreover, I did not 
know till later Francis B. Watson's Paul, Judaism and the Gentiles (1986), with his criticism of how Lutheran theology had determined the interpretation of righteousness in Paul.

Jewett puts up a contrast between the paradigm of justification as individual forgiveness and my focus on honour and shame as related to the central purpose of the letter, to bring together Jews and non-Jews in one community. Rereading my contributions to studies on Paul from the 1980s, I think that I was not so much concerned with that contrast as I was with contextualizing Paul's discourse on justification by faith in an honour and shame society, with the inclusion of Jews and non-Jews in one community as his goal. However, in hindsight I can clearly see that this approach served to displace righteousness as an individualistic theological concept and to focus on group relations. ${ }^{26}$

The values of honour and shame are relational; they belong to the social interactions within societies. Since honour is based on competition to gain recognition from others and to evade shame, people in honour and shame societies are always involved in comparisons with others. Paul's vocabulary in Romans reflects that he lived in an honour and shame society, but what distinguishes his use of this vocabulary is that he uses it not to increase competition but to establish equality. ${ }^{27}$ In the first section of his Letter to the Romans, Rom 1:18-3:21, Paul paints the human situation before or outside of the revelation of Christ in honour and shame categories. In this section kauchomai (to boast) is a crucial word that Paul uses to characterize Jews in their relations vis-à-vis others, when they boast that they have received the Law, 2:17, 23. This word played an important role in a Lutheran interpretation of Paul, for instance by Bultmann and Käsemann. ${ }^{28}$ According to this view, for Paul sin did not consist in human failings, but rather in the human desire to be self-sufficient, to make oneself into God. The most dramatic expression of that was boasting, i.e. making claims to honour for oneself. When Paul accused the Jews of boasting, it was interpreted as an indictment of all humans; the Jews represented the human sin to claim pride over against God.

This position held by Bultmann and Käsemann may have helped hermeneutically to apply the text directly to modern readers. However, it did not take Paul's historical context and the relational element in boasting into consideration. For Paul, boasting represented a specific Jewish claim to status based on their possession of the Law and of circumcision, Rom 3:27. ${ }^{29}$ In Rom 3:21-31 Paul establishes God's acts of justification by faith, and therefore he "clears away" boasting in order to include into one community Jews and non-Jews who were 
Christ believers. Paul's goal is that God shall be God not only of Jews but also of gentiles, and that circumcised and uncircumcised shall be justified by the same faith.

Paul's retelling of the Abraham story in Romans 4 puts the dialogue of question and response in 3:27-31 into a narrative form. Paul makes a link to the exclusion of boasting in 3:27 when he excludes Abraham from any right of boasting of his "works" (law, circumcision, 4:2), since God has granted him righteousness through faith (4:3). However, Abraham is not only an historic example of justification by faith. The main point for Paul in retelling the Abraham story is that because his justification was by faith, he became father for non-Jewish Christ followers together with Jewish ones (4:11-12, 16-18). As a righteous man, Abraham was the ultimate honorable ancestor. However, when Paul retells the stories of Abraham, he excludes all memories that in Jewish tradition were associated with his righteousness: his circumcision (Genesis 17) and the ultimate obedience towards God in his willingness to sacrifice his son (Genesis 22). For Paul, when Abraham was reckoned righteous, it was only on the basis of his faith in God and by God's grace $(4: 3,5,17,21)$. Moreover, it was because his righteousness was based on faith and not on his own works that he could become father of both circumcised and uncircumcised, Jews and non-Jews. Thus, Paul implies, justification by faith was not an individual experience, it became visible in the community of Jewish and nonJewish Christ followers in Rome.

\section{Goal: the One Community}

My studies of honour and shame brought a new dimension to the results of Theology in Conflict in that they provided a cultural context for Paul and his readers. Honour and shame made it possible to understand the mentalities and social structures of societies that were not based on individuals but on groups (households, kinship, villages, and city groups). The goal of my studies was to use insights in these mentalities and structures to understand Paulus letters; my motivation was not to salvage justification by faith as a central feature in Paul's writings. However, it turned out that I found overlapping interests. Whether I started from honour and shame perspectives or from texts with righteousness by faith as their main focus, I found that Paul had the same goal of including Jews and non-Jews into one community and of preserving the unity of the community.

This view was confirmed when I explored another approach to studies of Paul, viz. Paul in his Hellenistic Context. ${ }^{30}$ This approach has not received as much attention as the 
"New Paul" in his Jewish context, but in terms of relevance for the understanding of the style, form and philosophy of Paul's writings it is equally significant. Since Paul lived most of his life in the Hellenistic world of the Mediterranean, had a Hellenistic education and wrote (or dictated) his letters in Greek, this was obviously a primary context for him also as a Jew. Among Nordic scholars, Troels Engberg-Pedersen has most energetically explored the influence of Hellenistic philosophy, especially of Stoicism, upon Paul. ${ }^{31}$

In studies of Romans 3-4, I had explored Paul's concern for unity between Jews and non-Jews among Christ followers when he argued using examples from the Bible. When he makes a similar argument for unity in the community in Romans 12, however, he bases himself on well known ideas from moral philosophy. We find similarities to the positions in the Orations of the Stoic moral philosopher Dio Chrysostom (ca. 40-110 CE). ${ }^{32}$ In his criticism of Greek city states Dio was concerned that the elite would threaten the unity of the city with their competition for honor and for visible recognition of their status and benefactions. Dio was extremely critical that the craving for public reputation and honour would destroy both the economy and the internal cohesion in the city. In Paul's arguments in Romans 12 we find similar arguments drawn from Stoic moral philosophy.

A much used image for the unity of society was the human body, often in the form of a fable of the relation between the body and its members. In Roman writings, the elite often used this image as a warning to the plebeians that they must accept the rule of the head. Paul also uses the image of the body in Rom 12:5: "we, who are many, are one body in Christ, and individually we are members one of another." However, he uses this image in a different way; he is primarily addressing his advice to those of higher status, that they should not "think of yourself more highly than you ought to think, but to think with sober judgment," Rom 12:3. Since in moral philosophy competition for honour was regarded as one of the sources of divisions in societies, Paul advises those with higher status: "outdo one another in showing honor," 12:10. He concludes by exhorting them to be "of one mind", and "not be haughty, but associate with the lowly," $12: 16$.

These studies of honour and shame in Romans 3-4 and in Romans 12 suggested that Paul's concern for unity provided a thematic link between the two parts of the letter, the first often regarded as a discussion of justification by faith, the other consisting of moral exhortations to the groups in Rome. However, in both instances Paul is concerned to break 
down differences between groups in the community, be it on the basis of ethnic background or of status. A main, unifying approach in all these studies has been that Paul is not speaking to individuals, but to groups: Israel, Jews who were Christ followers, Christ following nonJews.

This theme of unity because of justification by faith is also the conclusion to Paul's retelling of the Abraham memory in Galatians 3. Since Abraham was justified by faith so were "those of faith," without distinction between non-Jews and Jews. Baptism into Christ establishes descent from Abraham and unites different groups: "There is no longer Jew or Greek, there is no longer slave or free, there is no longer male and female; for all of you are one in Christ Jesus," 3:28. Being "in Christ" represents a unity not only between Jew and Greek, but also between slave and free, male and female. Even if Paul developed his thoughts on no distinctions between Jews and non-Jews in the context of the conflict over the Law, his vision of unity between various groups was not limited to that context.

My perspective on Paul has been to see him as a Jewish proclaimer of Christ within the cultural context of the Greco-Roman world. The discussions in his letters are part of contemporary discourses on unity, traditions, moral obligations, faith in God, relations between various groups etc. Therefore, I find the discussions of the "New" or "Radical New" perspective too limited in their one-sided focus on Paul within "Judaism." In particular, I find the "radical New Perspective" with its claim that Paul did not criticize Jewish positions on Law and circumcision, and that Jews did not need Paul's message on salvation through faith in Christ, unconvincing and influenced by ideological positions. ${ }^{33}$ I find that I am closer to Francis Watson, who in his 1986 book launched a strong criticism of a Lutheran hegemony in the interpretation of Paul. In a new edition, however, he emphasizes, against "the new Perspective," that there was a conflict between Paul and Jewish positions. ${ }^{34}$ Using a sociological approach, Watson argues that in his letters Paul wanted to unite Jews and nonJews in one community. My approach above shares that perspective, and extends it to Hellenistic communities with their divisions based on differences in social class and gender.

\section{Reception History and new Perspectives on Paul}

Even if I was not consciously relating my studies of Paul to the issue of justification by faith, I still seemed to be asking for the centre of his arguments and positions. I consider it relevant to raise the issue of centre and consistency in the works of Paul or other ancient 
authors, but it is a question that can be addressed in various ways. "Justification by faith" was a response to the question of centre of Paul's system of thought, his theology, focusing upon the individual. If one instead, as I did, raised the question to Paul's letters addressed to communities, it was the unity of the community that was at the centre of Paul's arguments. ${ }^{35}$

To raise the question of the centre of Paul's letters has hermeneutical implications; we are interested in this question because we think that it will say something about the continuing relevance of Paul's positions. Thus, it is a question that involves us as readers of Paul; it requires a reflection upon our own role. Here reception history represents a new approach to legitimate reader involvement in the hermeneutical process. Inspired by Hans-Georg Gadamer and Hans Robert Jauss, reception history is an area of Biblical studies that has been growing quickly. ${ }^{36}$ It represents more than a history of theological interpretation in that it focuses on the active role of those who receive the text, whether it is in the form of writing, performing, arts, music etc. It represents an active engagement with the text and recognizes that this engagement by recipients is necessary to establish the meaning of a text. Therefore, reception history goes beyond the main goal of the historical critical method: to establish the original meaning in its historical context. The meaning established by the reception might "speak back" to the historical text, raise new questions and open up for new perspectives.

Paul's statements of unity in Gal 3:28 is a good example. The reception history of the passage reveals how these statements have been understood and used in very different contexts throughout history. ${ }^{37}$ A historical study of the argumentative context of Paul's sayings in the first century is a necessary starting point. ${ }^{38}$ However, the potential importance and relevance for later generations could hardly be recognized at the time of writing. Reception history thus opens up for larger perspectives upon Paul's discourse on the lives of Christ believers than we might have anticipated; it places the discussion of Jew/ Greek, slave/ free, male /female in a larger ideological and political context. Thus, studies of reception history serve to place modern readers at the end of a long process. As interpreters of the original text, we are challenged to confront contemporary discussions of these contrast pairs in light of previous discussions throughout the centuries. Today these questions require contemporary methods and theories to study race, class and gender. ${ }^{39}$ The resulting interpretation involves the issue of relevance since the categories used for historical interpretation are the same that come into play in our contexts. Thus, Gal 3:28 illustrates how 
interpretation represents a process where text, context, methodology and hermeneutics must be combined.

\section{Doing Contextual Theology with Paul}

This approach has influenced the way I have been teaching Paul's letters. ${ }^{40}$ The lectures on Paul that I heard as a student took for granted that he was a normative theologian and that his teaching on justification by faith was the centre of Christian, that is, Lutheran theology. Looking back upon the courses on Paul that I have taught in recent years, the situation is very different. First, there are fewer courses in New Testament, therefore only a small part of Paul's letters can be covered. There has also been an enormous growth and diversification in terms of methods of interpretation, requiring more discussions of theory. Finally, students generally know much less about Paul and many have a negative impression of him, particularly regarding his views on woman and homosexuality.

Thus, my priority has been to prepare students to master a complicated hermeneutical process in which Paul's letters are read against the contextual situation in the Mediterranean in antiquity, and to learn to use a variety of methods. Together with the students I wanted to raise the question: How did Paul do theology? Since Paul did theology within a context it is necessary to get to know the different contexts within which he worked. Moreover, if Paul did not address "the introspective conscience" of the individual, ${ }^{41}$ but groups and communities, we need to get to know these groups and their relations. I will use the interpretation of Gal $3: 28$ to illustrate the selection of literature the students have used over the last years. ${ }^{42}$

The classical study by Wayne A. Meeks, The First Urban Christians. The Social world of the Apostle Paul, is still unsurpassed in the way it helps students imagine the ancient cities as the contexts of Pauline communities. Meek's question: "What was it like to become and be an ordinary Christian in the first century?" 43 moves focus of investigation from Paul as an individual author to the collective experience and world view of the first Christians. As new groups "in Christ," they continued to live as members of their cities, but also separate, in part outsiders. This was even more noticeable in relation to the Roman Empire. The empire has often been an unrecognized force behind Paul's exhortations, but recent studies have made it visible as the power of the emperor that dominated the world of the early Christ followers. ${ }^{44}$ The Jewish context of Paul himself has been increasingly emphasized, but apart 
from the letters to the Galatians and the Romans, ${ }^{45}$ the interaction with the Hellenistic context is more prevalent. ${ }^{46}$

Gal 3:28 has proved to be useful to have students confront many relevant issues in the interpretation of Paul. The question whether Paul's "unity in Christ" represented a social, mental or eschatological crossing of boundaries presents a challenge. Statements like "no longer Jew or Greek" challenge us to confront contemporary issues of ethnic or racial conflicts. The implications of "No longer male and female" must be unpacked both historically and in contemporary debates. ${ }^{47}$ The last pair of contrasts, "no longer slave or free," has not received the same attention as the other pairs, but it is an important opening to understand ancient Mediterranean as slave societies and the social context of early Christian groups. Moreover, reception history tells how slavery in the course of history has become a test case of anthropology and human rights. ${ }^{48}$

Student evaluations appear to confirm that they considered this approach to be relevant. Some students mentioned that they had found that the picture they gained of Paul in this way was rather complex, but they realized the necessity of learning to live with complexity. The students' term papers seem to confirm these evaluations. Many papers showed strength in presenting the contexts of Paul's texts and the issues he raised. There was less time in the course to work on another goal, to reflect on how Christian faith and ethics can be expressed in different contexts. However, I think that the contextual way of working with Paul's texts provides students with analogies to their attempts to formulate Christian faith today.

Here I think today's students have an advantage over students of my generation. They live in a situation of cultural complexity, far from the situation of cultural unity that existed 50 years ago. Thus, studies of cultural complexity in our own contexts may help us to appreciate Paul's context as one of cultural complexity in the Hellenistic world. ${ }^{49}$ Such an approach has hermeneutical implications. The notion in my own student days of Paul as "canon" supported a hermeneutical model where the task was to transfer a theological content, justification by faith, to a new situation. However, the content remained the same. Students who now work with Paul as a theologian of cultural complexity will use a different hermeneutical model: the goal is not to transfer a specific content, but to learn a process where Christian faith is 
interpreted in new contexts. That means that central elements of faith by necessity must be expressed in dialogue with different contexts, in recognition of their cultural complexities. .

\section{Conclusion}

My own process in reading Paul has taken me from Paul as canon to seeing him in his context and reading him as a contextual theologian. This process is of course related to my personal experience of the changes that my own society, Norway, has undergone in the same period: from a homogenous monoculture to a society characterized by pluralism and cultural complexities. This has also had implications for the way I have been thinking of anthropology. I grew up with a Christianity where anthropology focused on the individual and individual faith, but the Viet Nam war, liberation of colonies and the civil rights movement in the USA expanded this anthropology with an awareness of social conflicts and the collective nature of humanity.

These experiences of social and mental transformations have of course influenced my reading and teaching of Paul's letters. By studying his context, I have become aware of the cultural complexity of his situation, combining Jewish, Hellenistic and Roman elements. Moreover, the discussions about integration of refugees and immigrants in European societies have made me realize what was at stake in Paul's efforts to establish a moral universe to support the integration of Jews and non-Jews. That is how I see him as a contextual theologian: meeting various conflicts and controversies with his reflections of what "being in Christ" meant for those who were involved in these conflicts. As a result, Paul has become more challenging and relevant to me.

\section{Bibliography}

Archetti, Eduardo. "Om maktens ideologi - en krysskulturell analyse", in Den norske varemåten. Ed. Arne Martin Klausen. Oslo: Cappelen, 1984, 45-60.

Buell, Denise K. Why this new Race? Ethnic Reasoning in Early Christianity, New York: Columbia, 2005.

Crossley, James C. Jesus in an Age of Terror. Scholarly Projects for a New American Century. London: Equinox, 2008. 
Nils A. Dahl. "Paul's letter to the Galatians: epistolary genre, content, and structure," in The Galatians debate. Ed. Mark Nanos. Peabody, Mass: Hendrickson Publishers, 2002, 117-42.

Engberg-Pedersen, Troels, ed. Paul in his Hellenistic Context. Edinburgh: T \& T Clark, 1994. Engberg-Pedersen, Troels. Paul and the Stoics. Edinburgh: T \& T Clark, 2000.

Esler, Philip F. Conflict and Identity in Romans. Minneapolis: Fortress, 2003.

Glancy, Jannifer. Slavery in early Christianity. Oxford: Oxford University Press, 2002.

Jervell, Jacob. Gud og hans fiender: Fors $\phi k$ på å tolke Romerbrevet. Oslo:

Universitetsforlaget, 1973.

Jewett, R. Romans: A Commentary. Hermeneia, Minneapolis: Fortress, 2007.

Jewett, R. Romans: A Short Commentary. Minneapolis: Fortress, 2013.

Joynes, Christine E. "Changing Horizons: Reflections on a Decade at Oxford University's Centre for Reception History of the Bible," JBRes 1 (2014): 161-71.

Kahl, Brigitte, Galatians re-imagined: Reading with the Eyes of the Vanquished. Minneapolis: Fortress, 2010.

Käsemann, Ernst, ed. Das Neue Testament als Kanon: Dokumentation und Kritische Analyse zur Gegenwärtigen Diskussion. Göttingen: Vandenhoeck \& Ruprecht, 1970.

Käsemann, Ernst. An die Römer. HNT 8 a, 3. ed. Tübingen: Mohr, 1974.

Lawrence, L. J., An Ethnography of the Gospel of Matthew. A critical Assessment of the Use of the Honour and Shame Model in New Testament Studies, WUNT 165, Tübingen: Mohr Siebeck, 2003.

Lønning, Inge. “Kanon im Kanon “: Zum dogmatischen Grundlagenproblem des neutestamentlichen Kanons. Forschungen zur Geschichte und Lehre des Protestantismus, 43, München: Kaiser, 1972.

Martin, Dale B. "The queer history of Galatians 3:28. 'No male and female'," in Martin, Sex and the single Savior: Gender and Sexuality in Biblical Interpretation. Louisville:

Westminster John Knox, 2006, 77-90. 
Meeks, Wayne A. The First Urban Christians. The Social world of the Apostle Paul. New Haven: Yale University Press, 1983.

Moxnes, Halvor. Theology in Conflict: Studies in Paul's Understanding of God in Romans. NovTSup 53; Leiden: Brill, 1980.

--- “Paulus og den norske væremåten. “Skam” og “ære” i Romerbrevet,” NTT 86 (1985): $129-40$.

--- $\quad$ "Honour and Righteousness in Romans" in JSNT 10 (1988): 61-77.

--- $\quad$ "Honor, Shame, and the Outside World in Paul's Letter to the Romans" in The Social World of Formative Christianity and Judaism. Ed. Jacob Neusner et al. Philadelphia: Fortress Press, 1988, 207-18.

--- $\quad$ "The Quest for Honor and the Unity of the Community in Romans 12 and in the Orations of Dio Chrysostom" in Paul in his Hellenistic Context. Ed. Troels Engberg-Pedersen. Edinburgh: T \& T Clark, 1994, 203-30.

--- $\quad$ "From Unique Personality to Charismatic Movement. 100 Yearsof Shifting Paradigms in Historical Jesus Research" in Religion in Late Modernity. Essays in Honor of Pål Repstad. Ed I. Furseth and P. Leer-Salvesen. Trondheim: Tapir, 2007, 187-200.

--- 'Race, Class and Gender 'in Christ?' The Ambiguous Reception History of Galatians 3:28," in Moxnes, A Short History of the New Testament. London: I.B. Tauris: 2014, 133-56.

--- "Does the History of the Canon Matter? Contextualizing the Debate over the Authority of the New Testament Canon," BTB 45:2 (2015): 108-15.

--- $\quad$ Social-scientific readings of the Bible, In The New Cambridge History of the Bible, vol. 4. From 1750 to the Present. Ed. John Riches. Cambridge University Press, 2015, 160 171.

Moxnes, Halvor; Ward Blanton \& James C. Crossley (ed.). Jesus Beyond Nationalism: Constructing the Historical Jesus in a Period of Cultural Complexity. Sheffield: Equinox, 2009.

Nashrallah, L. and E. Schüssler Fiorenza (ed.). Prejudice and Christian Beginnings. Investigating Race, Gender, and Ethnicity in Early Christian Studies. Minneapolis: Fortress, 2009.

Neutel, Karen B. A Cosmopolitan Ideal. Paul's Declaration 'Neither Jew nor Greek, Neither Slave nor Free, nor Male and Female' in the Context of First Century Thought. LNTS 513. London: Bloomsbury, 2015. 
Seim, Turid Karlsen. The Double Message : Patterns of Gender in Luke-Acts. Edinburgh: T\&T Clark, 1994.

Økland, Jorunn. Women in their place : Paul and the Corinthian discourse of gender and sanctuary space. JSNTSup 269. London: T\&T Clark, 2004.

Räisänen, Heikki. The Rise of Christian Beliefs. The Thought World of Early Christians. Minneapolis: Fortress, 2010.

Sanders, E.P. Paul and Palestinian Judaism: A Comparison of Patterns of Religion.

Philadelphia: Fortress, 1977.

Stendahl, Krister. "The Apostle Paul and the Introspective Conscience of the West," HTR 56 (1963): 199-215.

Watson, Francis B. Paul, Judaism and the Gentiles: a sociological approach. SNTSMon 56. Cambridge: Cambridge University Press, 1986. 2. Ed. Paul, Judaism and the Gentiles: Beyond the New Perspective. Grand Rapids: Eerdmans, 2007.

Halvor Moxnes,

Faculty of Theology,

University of Oslo,

P.o.box 1023 Blindern

N-0315 Oslo, NORWAY

halvor.moxnes@teologi.uio.no

\footnotetext{
${ }^{1}$ Räisänen, The Rise of Christian Beliefs.

${ }^{2}$ See Nils A. Dahl and Wayne A. Meeks in the bibliography.

${ }^{3}$ Moxnes, "Does the History of the Canon Matter?"

${ }^{4}$ Käsemann, Das Neue Testament, 399-410.

${ }^{5}$ Lønning, “Kanon im Kanon,” 21-23.

${ }^{6}$ Jervell, Gud og hans fiender, 7.
} 
${ }^{7}$ Jervell, Gud og hans fiender, 65.

${ }^{8}$ Käsemann, An die Römer, 85-95.

${ }^{9}$ Dahl was Buckingham Professor of New Testament at Yale University 1965-80. He was actively engaged in the inter-confessional Society of Biblical Literature, developing new approaches in the study of Pauline letters within the historical context of ancient epistolography, "Paul's letter to the Galatians."

${ }^{10}$ Moxnes, Theology in Conflict, 4-7.

${ }^{11}$ This focus on God has been recognized as proposing a new approach to the letter, cf. R. Jewett (Romans: A Commentary, 102): "Halvor Moxnes shows that throughout Romans, Paul emphasizes "the same God acting both in the history of Israel and in Jesus." This emphasis has its primary bearing not in theoretical and theological issues but in "the conflict between Jews and Greeks, high and low, insiders and outsiders." Most of Paul's statements about God in Romans were related to this situation in which he attempted to achieve unity through conflict."

${ }^{12}$ Moxnes, Theology in Conflict, 288-89.

${ }^{13}$ See a similar approach in Esler, Conflict and Identify in Romans.

${ }^{14}$ My colleague in Oslo, Turid Karlsen Seim (1945-2016), was a pioneer in feminist New Testament studies at Nordic universities, her Double Message won international acclaim.

${ }^{15}$ Moxnes, "From Unique Personality to Charismatic Movement."

${ }^{16} \mathrm{http}: / / \mathrm{www}$. contextgroup.org/.

${ }^{17}$ Especially Marianne Gullestad (1946-2008), Marit Melhuus and Thomas Hylland Eriksen, both at the University of Oslo.

${ }^{18}$ Crossley, Jesus in an Age of Terror, 110-35.

${ }^{19}$ Moxnes, "Paulus og den norske væremåten."

${ }^{20}$ Archetti, "Om maktens ideologi.“

${ }^{21}$ See a full list in Moxnes, "Honour and Righteousness," 77 n.15.

22 Jewett, Romans: A Short Commentary, 10.

${ }^{23}$ Moxnes, "Honour and Righteousness;" "Honour, Shame."

${ }^{24}$ Sanders, Paul and Palestinian Judaism from 1977 appeared too late to be included in my discussion. 
${ }^{25}$ Stendahl, "The Introspective Conscience of the West."

${ }^{26}$ For a criticism of the use of honour and shame as an argument that Early Christian groups represented a collectivistic culture, downplaying expressions of an individualistic culture found in New Testament texts, see Lawrence, An Ethnography of the Gospel of Matthew.

${ }^{27}$ Moxnes, "Honour and Righteousness."

${ }^{28}$ Watson, Paul, Judaism and the Gentiles, 34-35, 246-52.

${ }^{29}$ Watson, Paul, Judaism and the Gentiles, 249-50.

${ }^{30}$ Engberg-Pedersen, ed. Paul in his Hellenistic Context.

${ }^{31}$ Engberg-Pedersen, Paul and the Stoics.

${ }^{32}$ Moxnes, "The Quest for Honor."

${ }^{33}$ See the presentation and the criticism of the "Radical Paul" position in Neutel, $A$ Cosmopolitan Ideal, 111-26.

${ }^{34}$ Watson, Beyond the New Perspective, 1-26.

${ }^{35}$ Moxnes, Short History of the New Testament, 17-19.

${ }^{36}$ Joynes, "Changing Horizons."

${ }^{37}$ Moxnes, "Race, Class and Gender."

${ }^{38}$ An excellent study of Galatians 3:28 in its historical, first century argumentative context is now Neutel, A Cosmopolitan Ideal.

${ }^{39}$ There is an enormous amount of publications in this area, for a general overview, see Moxnes, "Social-scientific readings of the Bible." Related to Paul and Galatians 3:28 in particular, I have found especially helpful the following: Buell, Why this new Race?; Glancy, Slavery in early Christianity; Kahl, Galatians re-imagined; Nashrallah and Schüssler Fiorenza, (eds.), Prejudice and Christian Beginning; Økland, Women in their Place.

${ }^{40}$ See "Teol 4201 Paulus og paulinsk teologi" at the UiO webpage, http://www.uio.no/studier/emner/teologi/tf/TEOL4201/ accessed 15.072016.

${ }^{41}$ Stendahl, "The Introspective Conscience of the West."

${ }^{42}$ For complete lists of literature, check http://www.uio.no/studier/emner/teologi/tf/TEOL4201/ and click on Pensum, with lists from 2006-2016 available; accessed 15.072016.

${ }^{43}$ Meeks, First Urban Christians, 2. 
${ }^{44}$ Kahl, Galatians re-imagined.

${ }^{45}$ Watson, Paul, Judaism and the Gentiles.

${ }^{46}$ Engberg-Pedersen, Paul and the Stoics.

${ }^{47}$ Martin, "Galatians 3:28."

${ }^{48}$ Glancy, Slavery in Early Christianity.

${ }^{49} \mathrm{Cf}$. the strategic university programme, "Cultural complexity in the new Norway," at the University of Oslo 2004 - spring 2010, http://www.uio.no/english/research/interfacultyresearch-areas/culcom/.For an attempt to situate interpretations of Early Christianity in the context of cultural complexity, see Moxnes, Blanton \& Crossley (ed.). Jesus beyond Nationalism. 